\title{
RANBP2 wt Allele
}

National Cancer Institute

\section{Source}

National Cancer Institute. RANBP2 wt Allele. NCI Thesaurus. Code C114453.

Human RANBP2 wild-type allele is located in the vicinity of $2 \mathrm{q} 12.3$ and is approximately $66 \mathrm{~kb}$ in length. This allele, which encodes E3 SUMO-protein ligase RanBP2 protein, plays a role in both nuclear transport and protein SUMOylation. Mutation of the gene is associated with acute infection-induced encephalopathy 3. A chromosomal translocation $t(2 ; 2)(p 23 ; q 13)$ involving this gene and the ALK gene is associated with both inflammatory myofibroblastic tumor and, more rarely, myeloproliferative disorders. 